\title{
Independence and the Redefinition of Indianness around Santa Marta, Colombia, $1750-1850^{*}$
}

\author{
STEINAR A. SAETHER
}

Abstract. This article explores the changing meaning of Indianness during the long independence era. Focusing on six towns around Santa Marta, it discusses why these were considered Indian in the late colonial period, why they supported the royalist cause during the Independence struggles and how their inhabitants ceased to be identified as Indians within a few decades of republican rule. While recent subaltern studies have emphasised Indian resistance against the liberal, republican states formed in early nineteenth-century Latin America, here it is argued that some former Indian communities opted for inclusion into the republic as non-Indian citizens.

Indians play a passive or reactionary role in traditional views of the independence struggles and the formation of republics in Latin America. Several generations of historians of different political and academic backgrounds argued that independence was the work of the creole elites, exclusive groups of literate and often well-educated men at the apex of Latin American societies. This broad consensus on the sociological background of the leaders of the independence movements eventually resulted in a convergence of opinions on the nature of post-independence societies in Latin America. While nineteenth-century scholars largely viewed independence as a revolution or a series of such, historians writing in the second half of the twentieth century emphasised the continuities between the colonial and the so-called neo-colonial order. Schwartz and Lockhart summed up the wisdom prevalent at the beginning of the I980s when they claimed that "the degree of continuity between the social, economic, and cultural realms between preand post-independence ... is obvious and overwhelming. ${ }^{1}$

Steinar A. Saether is Associate Professor at Vestfold University College, Norway.

* The author thanks Rebecca Earle, Anthony McFarlane and the five anonymous JLAS readers for constructive comments to earlier versions of this article. Research was partly financed by the Norwegian Research Council. The following abbreviations are used: Archivo General de Indias (AGI), Archivo General de la Nación (AGN), Archivo Histórico Eclesiástico de Santa Marta (AHESM), Biblioteca Nacional (BN) and Notaría primera de Santa Marta (NPSM).

1 S. Schwartz and J. Lockhart, Early Latin America (Cambridge, I 983), p. 424. 
For historians taught to focus on the longue durée, to search for underlying structures and to write history from below, the independence era must have seemed like a long parenthesis filled with inconclusive battles, conspirational coups, legalist pamphlets and apolitical caudillos that ultimately had little significance for the development (or underdevelopment) of Latin American societies in the long run. This partly explains the relative scarcity of good studies on the era compared with the myriad of scholarly work devoted to the conquest period or the late eighteenth century. Over the course of the last few decades, however, a younger generation of historians has begun to change our understanding of independence, challenging both the elitist assumption (that independence and the formation of republics in were exclusively the work of creoles) and the continuity principle (that Latin America remained basically unaltered after independence).

With respect to the latter, François-Xavier Guerra has argued that independence represented the arrival of modernity and, more specifically, modern forms of sociability and political representation in Latin America. Echoing Jürgen Habermas, he claims that it was precisely during the independence period that media such as the printing press and newspapers as well as and elections formed a public sphere where in principle all members of society could participate irrespective of birth, ethnicity and social status. This meant, in Guerra's view, nothing less than 'the end of the old society and the entry into a new era ... the founding of a new man, a new society and new politics'. ${ }^{2}$ Latin American independence may thus be compared to the French revolution; indeed, it may be seen as an integral part of the liberal revolutions that swept across the western world in the late eighteenth and early nineteenth centuries.

Central to Guerra's argument is the fact that society changed because it was conceptualised in a radically new way. In other words, we are invited to leave behind the quest to uncover the fundamental material or social structures and to focus instead on the ways in which contemporaries thought, spoke and wrote about their own societies. Re-reading early republican texts, ceremonies and political events of different sorts, it is not difficult to see the great difference in how contemporaries represented their own society before and after independence. But this will hardly convince the sceptics. After all, social scientists have for two centuries questioned the validity of official state and elitist visions of the societies of which they were a part. And the question remains if this new republican society mostly existed in the minds of a few articulate elites, or if one can show that the folk (to use Bradford Burns' expression) of Latin America also participated in the formation of this new society.

${ }^{2}$ F. Guerra, Modernidad e independencias (Madrid, I992), p. I 3. 
This brings us back to the elitist assumption, the question of the Indians and their role in the independence movements and in the formation of national republics; not because non-elites were necessarily Indians, but because the questions of exclusion or withdrawal from the new national republics of the nineteenth century were particularly acute for those defined as Indians, and because the 'Indian question' reveals much about the nature of the new nations formed during independence and onwards.

The literature on Indians and state-formation in Latin America is vast, but has focused on groups that resisted the liberal concept of the republican state, fighting on the royalist side during the Wars of Independence or implicated in large-scale rebellions in the early republican period. Rather than seeing Indian support of royalism or Indian rebelliousness as evidence of political backwardness, traditionalism, or ignorance, recent studies have reanalysed Indian political participation and argued for a more comprehensive view of the political culture of Indian communities. Indian communities often had an alternative vision of their own political future, a vision which ran counter to both the Spanish royalist dream and the republican nation imagined by creoles. The work of historians such as Mark Thurner, Charles Walker, Florencia Mallon, Peter Guardino, John Tutino and Eric Van Young amongst others underlines in various ways both that Indian peasant communities envisaged a state different from that imagined by elites, andcontrary to the traditional view - that Indians did influence political developments and state formation on local as well as national levels. ${ }^{3}$ Indian military involvement is therefore not necessarily an indication that Indian communities shared the political outlook of elite leadership, but that they were able to modify and influence the political outcome of the wars and rebellions in which they fought. These recent studies of subaltern politics during the early republican period, then, emphasise the limited appeal of the liberal state as propagated by the elites and focus on attempts by peasants and Indians to shape political developments in the new republics.

This article, on the other hand, draws attention to an alternative experience after independence that has been a neglected theme in recent historiography: that certain Indian groups gave up on their Indianness, and opted for inclusion into republican society as common citizens. At first sight, this

3 M. Thurner, From Two Republics to One Divided: Contradictions of Postcolonial Nationmaking in Andean Peru (Durham, NC, 1997); C. Walker, Smoldering Ashes: Cuzco and the Creation of Republican Peru, I780-1840 (Durham, NC, I 999); F. Mallon, Peasant and Nation: The Making of Postcolonial Mexico and Peru (Berkeley, I995); P. Guardino, Peasants, Politics, and the Formation of Mexico's National State: Guerrero, I800-1857 (Stanford, 1996); J. Tutino, From Insurrection to Revolution in Mexico: Social Bases of Agrarian Violence, 1750-1940 (Princeton, I986); E. Van Young, The Other Rebellion: Popular Violence, Ideology, and the Mexican Struggle for Independence, I8I0-I82I (Stanford, 200I). 


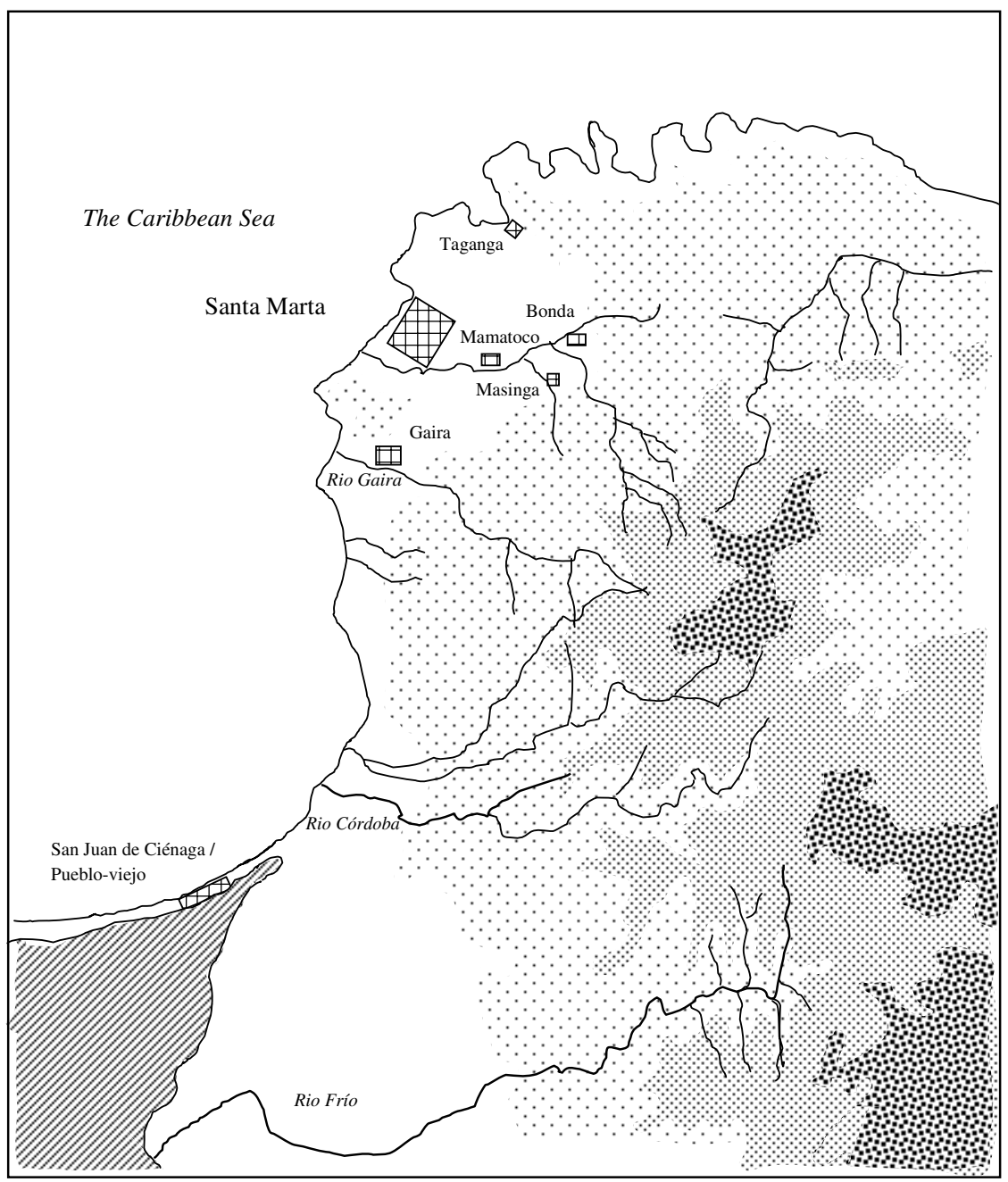

Map i. City of Santa Marta and Indian pueblos, late eighteenth century

may seem like an overly naïve understanding of the complex dynamics of identity formation following independence. But, I intend to show that for some communities labelled Indian by the late colonial state, Indianness was first and foremost a juridical and political position within the Spanish monarchy which opened avenues of collective political and judicial activity. With the establishment of a liberal, republican regime, Indianness became a less potent instrument and was abandoned by many communities. This perhaps will not surprise historians familiar with social developments in late colonial or early republican Latin America. Even the staunchest defenders of the continuity principle admit that the first half of the nineteenth century was 
Table I. Population of Indian towns around Santa Marta and city of Santa Marta 1793

\begin{tabular}{|c|c|c|c|c|c|c|c|c|c|}
\hline \multirow[b]{2}{*}{ Place } & \multicolumn{2}{|c|}{ Blancos } & \multicolumn{2}{|c|}{ Indios } & \multicolumn{2}{|c|}{$\begin{array}{l}\text { Libres de todos los } \\
\text { colores }\end{array}$} & \multicolumn{2}{|c|}{ Esclavos } & \multirow{2}{*}{$\begin{array}{l}\text { Total } \\
\mathrm{N}\end{array}$} \\
\hline & $\mathrm{N}$ & $\%$ & $\mathrm{~N}$ & $\%$ & $\mathrm{~N}$ & $\%$ & $\mathrm{~N}$ & $\%$ & \\
\hline San Juan de Ciéaga & 36 & 2.4 & 1236 & 83.2 & $2 \mathrm{I} 2$ & I 4.3 & I & 0.1 & 1485 \\
\hline San Jacinto de Gayra & $\circ$ & $\circ$ & 299 & 97.1 & 8 & 2.6 & I & 0.3 & 308 \\
\hline Mamatoco y Taganga & $\circ$ & ० & 389 & 100 & ○ & $\circ$ & ० & $\circ$ & 389 \\
\hline Bonda y Mazinga & o & 0 & 317 & 100 & o & 0 & 0 & 0 & 317 \\
\hline Total Indian towns & 36 & 1.4 & $224 I$ & 89.7 & 220 & 8.8 & 2 & $0 . I$ & 2499 \\
\hline City of Santa Marta & 499 & 13.9 & $2 \mathrm{I}$ & 0.6 & 2490 & 69.1 & $59 \mathrm{I}$ & 16.4 & 3601 \\
\hline
\end{tabular}

Source: Archivo General de Indias, Indiferente General I 527 . Santa Marta 1793 . 'Padron general que manifiesta el numero de personas havitantes en esta provincia de Sta Marta con distincion de clases, sexos y estados inclusos parvulos.'

characterised by a certain degree of social mobility and some blurring and re-definitions of ethnic and racial boundaries. The late colonial period offers numerous examples from all Spanish America that suggest the fluid character of definitions of race and ethnicity. But the processes approached here are different, because they are not about individuals who cross the line between the Indian and Spanish worlds, but about entire communities comprising several thousand inhabitants which in the course of one or two decades cease to be Indians in any meaningful sense of the term.

The article focuses on six small towns surrounding the city of Santa Marta: Mamatoco, Masinga, Taganga, Bonda, Gaira and Ciénaga (Map i). At the eve of independence, practically all the inhabitants of these towns were defined as Indians (Table I), whereas sometime before i 850 they ceased to be considered as such, and - what is equally important - no longer considered themselves to be Indian. These communities were already in the late colonial period hispanised to a large extent. Their members spoke Spanish, were devout Catholics, practised Christian marriage, had Spanish names and dressed like their urban commoner neighbours in the Spanish city of Santa Marta. They were nevertheless constantly defined as Indians until the very end of the Spanish regime, because as descendants of the indigenous preconquest population they held certain legal and political privileges. For these Indians then (and I suspect for many others in Spanish America), by the end of the colonial period Indianness was first and foremost a legal and political category. With the formation of the republic of Colombia (which, incidentally, the tagangas, bondas, gairas, mamatocos, masingas and cienagueros opposed to the bitter end), that legal and political definition of Indianness became irrelevant, and the term 'Indian' was henceforth reserved for those groups which lived on the margin of Colombian society and who were more decisively culturally different from the 'normal' (non-Indian) citizens of Colombia. In other 
words, a large proportion of those identified as Indians in the late colonial period, were no longer Indians two or three decades after independence.

To explore this process we need to consider first the possible elements of Indianness. Which were the criteria that set Indians apart from non-Indians in the late colonial period? The political and juridical dimensions of Indianness became a central issue during the independence era, and will be discussed as the second part of this article. The last section outlines some of the fundamental modifications in the definition of Indianness during the first decades after independence, and the extent to which the former Indians participated in the new politics of the republican era.

There are three main approaches to defining Indianness in the late colonial period: the racial, the ethnic/cultural, and the juridical/political. The racial perspective, although perhaps not completely abandoned, has been significantly modified by historians working on the late colonial period, and largely subsumed within a cultural or ethnic view on the difference between Indians and non-Indians. A purely racial view would hold that Indians were separated from non-Indians first and foremost by the way they looked. But, as Martin Minchom and Douglas Cope have convincingly shown, phenotype was a notoriously vague marker by the eighteenth century in Spanish America. ${ }^{4}$ Most historians of the late colonial period now tend to view the Indian-Hispanic divide as primarily a cultural one: Indians were identified by their place of birth, place of residence, by their dress, by their hair-do, by their diet and in some cases by their language and religion. But in addition to the possible cultural differences between non-Indians and Indians a set of legal regulations had been formed continuously since the sixteenth century which clearly separated Indian communities from non-Indian ones with respect to a host of issues concerning political organisation, taxation, land and fishing rights to name just a few that were especially important to the communities discussed here. Indians living in Indian towns constituted, in other words, a specific juridical and political body within the monarchy. The distinction between a cultural definition and legal one is essential, because it implies that legal Indian communities may have been thoroughly hispanised; a community of Spanish-speaking Catholics were not necessarily less Indian under Spanish law than a community of non-Spanish-speaking heathens. On the contrary: the object of much Spanish legislation was not to preserve Indian traditions and customs but convert them into good subjects of the Catholic monarch. The major issues here concern to what extent this juridical otherness was reflected in a special Indian identity, to what extent the

4 M. Minchom, The People of Quito, 1690-1810: Change and Unrest in the Underclass (Boulder, 1994); R. D. Cope, The Limits of Racial Domination: Plebeian Society in Colonial Mexico, 1660-I720 (Madison, I994). 
juridical separateness coincided with cultural differences, and what effects the abolition of much of the Indian legislation had on the interior life of the former Indian communities during the early republican era. When communities that had been Indian in a legal sense ceased to be recognised as such by the republican state, and when Indians became citizens, what were the effects on the local communal traditions and identities? Was it possible for these Indians to imagine a republican nation in which they would be a part, or were these juridical and political changes merely a part of a republican rhetoric that had no or little consequence for the everyday lives of the LatinAmerican folk?

\section{Colonial patterns}

The masingas, cienagueros, mamatocos, tagangas, bondas and gairas were constantly defined as Indians until the end of the colonial regime, but they appear not to have been culturally very different from their Hispanic commoner neighbours in the city of Santa Marta. Admittedly, our knowledge of these communities is limited, in part because historians and anthropologists have shown a greater interest in the more exotic groups who remained unconquered throughout the colonial period and who are still widely regarded as Indians such as the guajiros, arbuacos, chimilas and motilones. ${ }^{5}$ The lack of modern anthropological and historical studies of these towns, is further compounded by eighteenth-century observers who wrote surprisingly different accounts of the tribute-paying Indians around Santa Marta. Antonio Julián, a Jesuit who lived in Santa Marta in the 1750 s, held that ' $\ldots$ all these are pacified Indians, already reduced to religion, they live with their respective parish priests, they are subjects of God and of their catholic monarch, and they are distinguished more by their Christian character than by any vestiges of their old barbarian nations. ${ }^{6}$ His view of thoroughly hispanised communities contrasts with a description written by José Nicolás de la Rosa only twenty years earlier for whom the tributary Indians Santa Marta differed from their Hispanic neighbours in their physical appearance, in their manners, in their diet, their clothing and in their fondness of drink, although he admitted that they spoke Spanish 'with some clarity' and only used Indian languages in ceremonies and dances. ${ }^{7}$

${ }^{5}$ For a fuller discussion see S. A. Saether, 'Identities and Independence in the Provinces of Santa Marta and Riohacha (Colombia), ca. 1750-ca. i 850 ,' unpubl. PhD dissertation, University of Warwick, 200I. This work will be published in Spanish by the Instituto Colombiano de Antropología e Historia in 2005.

6 A. Julián, La perla de América, Provincia de Santa Marta (Bogotá, I95 I), p. I74. On Julián, see J. O. Melo, 'La coca, planta del futuro. Un texto del siglo XVIII,' Credencial historia, no. I 58 (Feb. 2003).

7 J. N. de la Rosa, Floresta de la Santa Iglesia Catedral de la ciudad y provincia de Santa Marta (Bogotá, I975), p. 281. 
Other sources support Julián's description and suggest that at least by the end of the eighteenth century these Indians were thoroughly hispanised. Hispanisation had begun in the first half of the sixteenth century. In the course of the first centuries of colonial rule, the villages around Santa Marta underwent a series of profound transformations. The towns were conquered and 'pacified' during the sixteenth century by conquistadors attracted by the golden artefacts of the Tayrona and in need of the harbour provided by the bay of Santa Marta. Despite the natives' prolonged and violent opposition, by 1600 the Spanish succeeded in subduing the towns nearest the city while large groups of unconquered Indians remained in the upper reaches of the Sierra and in the more remote corners of the province. ${ }^{8}$ The Indian communities near the city were turned into encomiendas held by leading conquistadors and their descendants. Slaving raids, disease, forced migrations and the general demographic decline throughout the sixteenth and seventeenth centuries resulted in a constant reduction and regrouping of the encomiendas from the mid-seventeenth century onwards. At the beginning of the eighteenth century all encomiendas in the province of Santa Marta reverted to the crown. By Royal Decree of I I September I70I, the inhabitants of the pueblos de indios were obliged to pay an annual tribute to the Crown set at four pesos, payable in money or in kind. Henceforth, the Indians of the five towns near Santa Marta were regularly described as tributary Indians to distinguish them from the still unconquered Indian groups elsewhere in the province and from those recently subdued Indians living in missions temporarily exempt from the tribute. ${ }^{9}$

The tributary Indians of the late eighteenth century were not simply the descendants of the pre-Hispanic inhabitants of their own villages; their

8 H. Bischof, 'Indígenas y españoles en la Sierra Nevada de Santa Marta - Siglo XVI,' Revista Colombiana de Antropología 24 (1982), pp. 77-1 24; G. Reichel-Dolmatoff, 'Contactos y cambios culturales en la Sierra Nevada de Santa Marta,' Revista de Antropología I (1953), pp. I7-I 22; Reichel-Dolmatoff, Datos histórico-culturales sobre la antigua gobernación de Santa Marta (Bogotá, I 95 I); N. del Castillo Mathieu, 'Población aborígen y conquista I 498-1 540,' in A. Meisel Roca (ed.), Historia económica y social del Caribe colombiano (Bogotá, I 994); C. J. Mathers, 'Santa Marta Gold: Spaniards in Colombia, I 5 26-1 536 ,' Colonial Latin American Historical Review, vol. 4, no. 3 (1995), pp. 287-310; H. Tovar, La estación del miedo o la desolación dispersa. El caribe colombiano en el siglo XVI (Bogotá, I 997); E. Restrepo Tirado, Historia de la provincia de Santa Marta 2nd ed. ist vol. (Bogotá, 1953).

9 J. A. Villamarín and J. E. Villamarín, 'Chibcha Settlement under Spanish Rule: I $537-18$ 1 o,' in D. J. Robinson (ed.), Social Fabric and Spatial Structure in Colonial Latin America (Ann Arbor, I 979), pp. 25-84; M. González, El resguardo en el Nuevo Reino de Granada 2nd ed. (Bogotá, i 979); M. Mena García, 'Santa Marta durante la guerra de sucesión española,' Anuario de estudios americanos, vol. 36 (I979), pp. 569-702; L. Luna, Resguardos coloniales de Santa Marta y Cartagena y resistencia indigena (Bogotá, 1993); M. Herrera Angel, Ordenar para controlar: ordenamiento espacial y control politico en las Llanuras del Caribe y en los Andes Centrales Neogranadinos. Siglo XVIII (Bogotá, 2002). 
populations included people from the entire area around Santa Marta. Father Julián observed in the 175 os that '... these Indians are known solely by the name of the village in which they live, and they do not have any knowledge any more of what nation or tribe they used to belong to. ${ }^{\mathbf{1 0}}$ The six existing towns at the end of the colonial period were the result of a continuous re-settlement process whereby the tributary population of small towns were moved to the larger as the population declined. ${ }^{11}$ There is evidence suggesting that the late colonial inhabitants of the tributary towns also descended from native groups farther away. Reichel-Dolmatoff surveyed surnames common in the 1743 censuses of Mamatoco and Gaira, found that some probably originated in the Magdalena river area. ${ }^{12}$ Natives from the lower Magdalena valley were taken to Santa Marta as prisoners in the sixteenth century, and it is likely that some were incorporated into the Indian villages close to the city.

The heterogeneous ethnic origin of these towns probably facilitated the adoption of Hispanic cultural elements. For instance, Spanish surnames appear to have been adopted from the conquistadors, encomenderos and governors of the sixteenth century. Some of the most common surnames in the towns around the city of Santa Marta, such as Manjarrés, Nuñez, Incapié and de Silva were probably borrowed from I6th-century Governor Luis de Manjarrés and encomenderos Diego Núñez, Pedro Martín Hincapié, and Victoria de Silva. ${ }^{13}$ Likewise, no mention is made in the known sources from eighteenth century that parish priests needed knowledge of any native tongue in order to serve in the pueblos.

Family formation is central the continuous construction of group identities, and some of the most revealing sources at our disposal testify to the thorough hispanisation of these communities with respect to the sacrament of marriage. An admittedly crude but nevertheless telling index of marriage practices is the marriage quotient; the percentage of married individuals in a given population. In 1793 the marriage quotient in these tributary towns was 32.9I, which means that relatively more Indians were legitimately married than non-Indian commoners or even Spanish elites in some cities of the province. $^{\mathbf{1 4}}$ This orderly marriage pattern contrasts sharply with the extremely low marriage quotients for the slave and mission populations. While

10 Julián, La perla, p. 174.

11 T. Miranda Vázquez, La Gobernación de Santa Marta (I570-1670) (Sevilla, I976); Luna, Resguardos, Mena García, 'Santa Marta’; A. Bermúdez Bermúdez, Materiales para la bistoria de Santa Marta (Bogotá, I981).

12 Reichel-Dolmatoff, 'Contactos', p. 54-5; AGN, Censos 6, folios 583-7; AGN, Censos 8, folios 294-9; AGN, Caciques e indios 9, folios 769-88, and 1793 census in AGI, Indiferente general i 527 .

14 Saether, 'Identities and Independence', pp. $65-185$. 
friars repeatedly denounced the polygamy and disorderly marriage practices among recently converted Indians living in missions in the higher reaches of the Sierra Nevada or near Riohacha, such complaints are all but unknown from the tributary towns. ${ }^{15}$ In other words, there is little doubt as to the effective internalisation of Catholic marriage customs by the tributary Indians.

One might object that tributary Indians throughout Spanish America secretly maintained elements of indigenous culture, particularly religious practices that had to be hidden from Catholic priests and other agents of the Spanish state which then only exceptionally are recorded in the sources. ${ }^{\mathbf{1 6}}$ Although no accusations of heretical practices are known from these towns, we might speculate that the tributary Indians around Santa Marta continued to resist cultural domination and secretly practised unauthorised rituals or that certain elements of pre-Columbian religion were imbedded in their Catholicism. Such an assertion would nevertheless miss the main point: that their Indianness was not defined primarily in cultural terms. Any examples of syncretism or vestiges of pre-conquest religions would not make them any more Indian under the law. And, conversely, the lack of pagan beliefs or practices, the loss of native language, and the thorough hispanisation of these communities did not make them any less Indian.

Furthermore, the political institutions and position that governed the interior of the tributary towns were not modelled on pre-Hispanic native institutions, but were introduced by the Spanish in the sixteenth century for the internal government of the Indian communities. The very names of the positions were all Spanish, except for cacique. The apparent continuation of older systems of power, such as the requirement of the caciques to show that they had a hereditary claim to the title before being appointed by Spanish authorities, only constitutes a double set of novelties in that the original matrilineal system prevalent in the area was replaced by an Iberian patrilineal one. ${ }^{17}$

15 Lance Grahn, 'Guajiro Culture and Capuchin Evangelization: Missionary Failure on the Riohacha Frontier,' in Erick Langer and Robert H. Jackson (eds.), The New Latin American Mission History (Lincoln, NE, I995) and E. Barrera Monroy, Mestizaje, comercio y resistencia: La Guajira durante la segunda mitad del siglo XVIII (Bogotá, 2000).

16 S. Gruzinski, The Conquest of Mexico: The Incorporation of Indian Societies into the Western World, I6th-I8th Centuries (Cambridge, I993); K. Mills: An Evil Lost to View? An Investigation of Postevangelisation Andean Religion in Mid-colonial Peru (Liverpool, I994); F. Cervantes: The Devil in the New World. The Impact of Diabolism in New Spain (New Haven, I994); N. Farriss: Maya Society under Colonial Rule: The Collective Enterprise of Survival (Princeton, I984); J. Lockhart: The Nahuas After the Conquest: a Social and Cultural History of the Indians of Central Mexico, Sixteenth through Eighteenth Centuries (Stanford, 1992).

17 That matrilineal descent continued to have some importance in these towns can be deduced from the assertion of de la Rosa that those men who had facial hair ' ... es reputado entre ellos por mixto; mas no dejan de reconocerlo por indio, porque pesa más en su opinión el seno materno que la aptitud del varón', de la Rosa, Floresta, p. 28 I. 
Thus in the counts of tributary Indians, the oldest son of the present cacique was normally identified. ${ }^{18}$

Hispanisation did not necessarily mean loss of identity and political feebleness. Indeed, at the end of the eighteenth century, and perhaps even more than in previous centuries, the tributary towns were vital communities able to defend what they perceived to be their rights and traditions and to make successful use of the Spanish legal system. This - somewhat paradoxically suggests that the maintenance of the separate political identity in part depended on an embrace of Hispanic culture. In that respect, the pueblos around Santa Marta seem to have developed in a very different manner from those of the interior of New Granada. There the pueblos came under enormous pressure in the late colonial period: their lands were sold, outsiders moved into the villages, married local women and took control over the local political institutions to the extent that by the late eighteenth century Indians constituted a numerical minority in most towns. ${ }^{19}$ Around Santa Marta, on the other hand, the tributary towns flourished before independence. Although the towns were small, several sources indicate that they were strengthened both in demographic and political terms in the last decades of colonial rule. They experienced a veritable demographic growth, nearly all inhabitants were still defined as Indians, they managed to maintain control of local political institutions and they fought wealthy creoles with remarkable efficiency through the colonial judicial apparatus.

Eighteenth-century censuses indicate both that the vast majority of the inhabitants were Indians and that the population increased significantly. In Mamatoco, Taganga, Bonda and Masinga all inhabitants were categorised as Indians except for the priest, and in Gaira there were only eight 'free people of all colours' and one slave. The much larger town of Ciénaga had a slightly more heterogeneous population according to the 1793 census with its 1236 Indians, 2 I 2 'free people of all colours', 36 'whites' and one slave. Overall, the 1793 census offers a clear-cut picture repeated in the I 804 counts of male inhabitants: these towns were overwhelmingly 'Indian' at the eve of independence. Unlike their counterparts in the interior, the pueblos around Santa Marta were not destabilised by massive immigration of outsiders, nor do they seem to have been weakened by particularly high rates of emigration. ${ }^{20}$ In fact, all these communities experienced a considerable demographic growth

18

I 743 census of Mamatoco in Bermúdez, Materiales, p. 76. For genealogy of notable Indians in Ciénaga, see 'Testimonio de los documentos que acreditan la ascendencia de José Vicente del Rosal por ambas lineas' i 79 i in AGI, Santa Fe i i 97. On cacicazgos in Ciénaga, see 'Manuel Manjarrés solicita el cacicazgo de la Ciénaga en la provincia de Santa Marta,' i 8 I , AGN, Solicitudes io, folios I-2.

19 See note 9.

20 In the counts of males conducted in 1743 and I 804 the census-takers listed fugitives, but the number recorded never exceeded ten in any of these towns. 
in the eighteenth century. For instance, Gaira had roo adult male Indians in 1627, only i 8 in I661, 26 in 1743 and 91 in 1804 . Total number of Indian males in Gaira was 60 in 1743 and 257 in I 804. Admittedly, these numbers conceal the fact that the number of tributary towns decreased constantly from the sixteenth century so that while there had been around 30 encomiendas in the beginning of the seventeenth century, only six pueblos remained around Santa Marta at the eve of independence. Nevertheless, the reported number of tribute-paying Indians was actually larger in 1804 than in 1627 . The rising demographic figures of the second half of the eighteenth century are so remarkable that they may not accurately reflect population growth alone. More efficient administration and a stronger emphasis on forcing people to live in urban centres probably inflated census figures. Still, the population almost certainly increased, also indicated by the age distribution of the tributary population in the second half of the eighteenth century, when the number of children and youth far outnumbered the number of adults and elderly.

The censuses cannot be read as neutral guides to the social make-up of eighteenth-century society. Representatives of the Bourbon state constructed them, after a scheme developed by the Council of Indies, and they reproduce an official and normative view of how the demographics of the province should be: white Spaniards should live in cities along with slaves and commoners while Indians should live in tributary towns. Still, other sources confirm the impression of Indian domination within the pueblos. Marriage records show that the inhabitants of these towns only very rarely married outsiders. Of the 770 people who married in the city of Santa Marta between 1772 and 1788 , only two brides and no grooms were originally from the pueblos. ${ }^{21}$ Conversely, hardly any outsiders married in the Indian parishes. Of 109 marriages in the parish of Gaira between 1783 and I 810 , only three grooms and no brides were stated to be of other parishes. ${ }^{22}$ This insularity is further corroborated by the repeated occurrences of the same surnames in censuses and parish records. The vast majority of the grooms listed in marriage books from Gaira between 1783 and 1809 can be found also in the counts of male population of Gaira from I 804. ${ }^{23}$ In Gaira in I804, of the 102 tributary Indian males listed 39 had the surname Manjarrés, I 5 Eguí, I I Incapié, eight Boto and eight de Silva. These same surnames recur in the

21

Until i 8 I the city of Santa Marta had only one parish which maintained two separate marriage books: 'Libro de matrimonios de blancos descendientes de españoles' included the marriages of a small group of notable families, and 'Libro de matrimonios de pardos, mestizos, negros' (hereafter LPMN with all other marriages between 1772 and 1788 . The two marriages cited are found in AHESM, LPMN 29 Dec. 1784 and 20 Feb. 1775.

22 Libro de matrimonios de Gaira $1783-1850$ (hereafter LG) in AHESM.

23 The main exceptions are the eight slave couples who married in Gaira. They probably worked on the sugar plantations nearby. 
marriage records and other lists of inhabitants. ${ }^{24}$ Similar patterns are visible in the other tributary towns around Santa Marta. ${ }^{25}$

There are other signs, too, of a revitalisation of the tributary towns towards the end of the colonial period. In the central highland areas of New Granada, wealthy non-Indians had usurped the local judicial and political institutions in the Indian towns. ${ }^{\mathbf{2 6}}$ Not so in the towns around Santa Marta. Here the tributary Indians maintained control over local political institutions, and in each tributary town there were political representatives appointed by Spanish authorities but recruited among the Indian residents. In the largest towns the number of representatives could be large, such as in Gaira where there were one cacique, three alcaldes, two regidores, a capitán, one fiscal and a sacristán to aid the parish priest in 1804 , all recruited from the tributary population. ${ }^{27}$ In the smaller towns such positions were fewer. In Taganga in 1743 there were only a cacique and an alcalde. ${ }^{28}$ The fact that these officials were recruited from the Indian community may serve as another indication that the towns around Santa Marta were able to use the Spanish system to their own advantage.

Through this relative political autonomy the Indian pueblos were able to engage in protracted legal conflicts with neighbouring landowners. These disputes were generally over land, grazing and fishing rights, and usually involved conflicts over the measurement of the resguardos and the private plantations and ranches owned by elites. In Ciénaga, the Indians sustained a legal dispute with some of the most prominent of the noble families of Santa Marta for at least forty years. ${ }^{29}$ To the east of Ciénaga lay the large plantations of Santa Cruz de Papare and Garabuya, the two largest sugar plantations of the province of Santa Marta. Founded on the shores of the river Toribio by Governor José Mozo de la Torre, in 1753 the properties were sold to the Núñez Dávilas, who made part of the close network of noble families in the city of Santa Marta. ${ }^{30}$ Despite the formidable influence of their

24 Apart from censuses already listed, see 'Lista de los naturales que voluntariamente quieren trasladarse de su Pueblo de Gayra a las tierras de Rio Frío' in AGN, Resguardos i 2, folios 404-6.

25 In Taganga the most common surnames were Basques, Daniel, Matos, Yaritama and Doy, and in Mamatoco the most common were Nuñez, Duica, Sifuentes, Cuchara and Peña. AGN, Censos 8, folios 294-9. $\quad{ }^{26}$ See note 9. $\quad{ }^{27}$ AGN, Censos 6, folio 583.

28 Bermúdez, Materiales, p. 8I. $\quad{ }^{29}$ AGN, Resguardos i 2, folios I-294.

30 M. T. Vargas, Anotaciones históricas del Magdalena (Bogotá, 1948), pp. 7 I-6, although there are some errors in his genealogical data; 'Escritura de venta de 27 fanegas de tierra a favor de Nicolás Martínez de los herederos de Francisco Josef Núñez Dávila,' in AGN, Resguardos I 2, folios 76 ff; 'Testamento de José de Ximeno,' n.d. in NPSM Protocolos de i 829 ; 'Testamento de Pablo Oligós,' i7 April i 8 I 7 in NPSM Protocolos de 1817 ; 'Testamento de José Nicolás de Ximeno' i 3 Jan 1820 in NPSM Protocolos de i 819-1820; H. Tovar, Grandes empresas agrícolas y ganaderas (Bogotá, 1980), pp. I 36-7 and anexo 7; Bermúdez, Materiales, p. 274; D. Romero Jaramillo, Esclavitud en la provincia de Santa Marta I79I-I85I (Santa Marta, 1997), pp. 92-8. 
opponents eventually succeeded in securing the rights to most of what they claimed. Similar conflicts over land between the tributary towns and large plantations occurred all over the province. The Indians of Mamatoco fought for lands in the vicinity of their towns against the pretensions of deacon Francisco Muñoz Castellanos. ${ }^{31}$ Moreover, later they came in conflict over land with José Francisco Múnive y Mozo, colonel of the militias of Santa Marta and owner of the sugar plantation Santa Cruz de Curinca. ${ }^{32}$

Before independence, then, the tribute-paying towns around Santa Marta were strong local communities, under pressure from the expanding sugar plantations and other private properties held by local creoles, but still a long way from the dismal decay which we are told characterised the Indian tributary towns in the interior of New Granada. They used Spanish institutions and colonial law to resist encroachments from local elites. This resistance against wealthy non-Indians, however, should not be taken as a sign that the tributary towns were merely remnants of pre-conquest communities opposing acculturation, in eternal resistance to Spanish domination. Such a dualistic vision is not supported by available primary sources. Although our knowledge of the cultural development inside the towns is limited, there is little evidence to suggest that the inhabitants of the tributary Indian towns around Santa Marta were culturally very distinct from their Hispanic commoner neighbours. On the contrary, from a cultural perspective these Indians were remarkably non-Indian. For their Indianness was based on genealogy: as the descendants of the original population they were by law Indians and therefore had a specific legal and political status within the Spanish monarchy. Tributary Indians enjoyed various corporate political and legal privileges in accordance with what was perceived to be the natural rights of any indigenous population. In the eyes of the crown their adoption of Hispanic culture only made them more justified in these privileges.

\section{The wars of independence}

The Indian towns around Santa Marta played an important role during the wars of independence. They were soon reputed to be among the most fervent defenders of the crown, and partly due to their continued political activism Santa Marta became one of the most significant royalist strongholds on the northern coast of South America during the independence period.

31 'Mensura y asignación de tierras a los naturales de Mamatoco con oposición de Francisco Muñoz Castellanos, deán de la catedral de Santa Marta,' I779-1782 AGN, Resguardos I 2, folios $295-387$.

${ }^{32}$ For property owned by José Francisco Múnive y Mozo, see his will given in Santa Marta 8 Jan. I 834 i NPSM, protocolos I 834-35. The conflict is described in a letter by José María Martínez de Aparicio to the King, 25 Nov. 18 Io in AGI, Santa Fe 746 and in the 36 acta of the Junta de Santa Marta, 24 Nov. I 810 in AGI, Santa Fe 746. 
How can this persistent royalism be explained? Traditional views have focused on the limited circulation of enlightenment ideas in Santa Marta and the supposed traditionalism of the tributary Indians. ${ }^{33}$ In a recent article, however, Rebecca Earle has shown that Indian royalism was a basic tenet of both republican and royalist rhetoric at the time, and has been repeated more or less uncritically by historians ever since. ${ }^{34}$ One should, then, treat any information of Indian royalism with utmost caution. But in this particular case, to dismiss all the primary sources from Santa Marta as rhetorical constructs engineered for political purposes would be an act of exaggerated scepticism. Whereas it is hard to generalise about the political role of Indian communities in Spanish America as a whole during the independence period, the case of Santa Marta seems clear-cut. The difficult task is not to establish that the tributary Indians fought for the royalists but rather to explain why they did.

One possible explanation is the longstanding conflict between Indians and wealthy creoles over land. This may have been a sufficient reason for the tributary Indians around Santa Marta to side against the creoles and in favour of the peninsular royalists. There are certainly examples of old territorial conflicts becoming intertwined with the political struggles of the independence era, for instance between the mamatocos and Colonel José Francisco Múnive y Mozo over the measurement of his hacienda Santa Cruz de Curinca and the resguardos of Mamatoco. Múnive y Mozo was one of the most prominent vecinos of the city of Santa Marta, related by birth and marriage to a coastal network of notable families, who although not openly in favour of the patriot cause, were suspected of secretly supporting the republicans. ${ }^{35}$ Múnive y Mozo was the highest-ranking militia officer in Santa Marta at the eve of independence, commanding the two militia companies of the city, and one of the wealthiest inhabitants of Santa Marta, later reported to own seven houses in the city, four undeveloped urban properties, a cattle ranch in Sitionuevo in addition to the sugar plantation of Santa Cruz de Curinca. In the view of the royalist peninsulares, Múnive y Mozo was one of the most formidable enemies of the Regency Council, precisely because as the commander of the militias, he had the entire regiment under his orders, and because of his wealth which bestowed him with many friends. ${ }^{36}$ And it was in Múnive y Mozo's house

33 Jorge Conde Calderón, 'Poder local y sentimiento realista en la independencia de Santa Marta' Historia caribe, vol. 2, no. 4 (I 999), pp. 77-86; Adelaida Sourdis Nájera, 'Ruptura del estado colonial y tránsito hacia la república I 800-1850,' in Meisel Roca (ed.), Historia económica, pp. I 5 5-228.

${ }^{34}$ Rebecca Earle, 'Creole Patriotism and the Myth of the "Loyal Indian",' Past and Present, no. I 72 (200I), pp. I $25-45$.

${ }^{35}$ For genealogical information see M. C. Guillén de Iriarte, Nobleza e bidalguía en el Nuevo Reino de Granada: Colegio Mayor de Nuestra Señora del Rosario 165I-I8IO (Bogotá, 1994) and Múnive's will in NPSM, protocolos I 834-35.

36 AGI, Santa Fe 746. Letter from Martínez de Aparicio, 25 Nov. i 8 Io. 
that several revolutionary texts were read in August i 8 1 0 for thirteen of the most prominent vecinos. ${ }^{37}$ Thus, in Múnive y Mozo the tributary Indians of Mamatoco had a powerful opponent, and it is a testament to their political strength that they were able to counter his influence and retain their common lands. This they accomplished through the threats of violence although it seems they seldom resorted to actual employment of it - the effective use of Spanish legal instruments and, perhaps most importantly, through the alliance with peninsular officials. On 23 November i 8 ro the Indians of Mamatoco caused a commotion because the governor had not fulfilled his promise of arranging the measurement of the land in dispute between the mamatocos and Múnive. The governor did not dare to go personally to Mamatoco without the escort of a militia company. Instead, the peninsular official José María Martínez de Aparicio volunteered. A fierce royalist, he had lived in Santa Marta for more than 30 years and was respected by the surrounding communities. In an admittedly self-laudatory note to the Regency Council Martínez de Aparicio explained that he walked to Mamatoco only accompanied by the treasurer of the cathedral chapter, and managed to calm the anger of the mamatocos by allowing three representatives to present their case before the Junta and by offering roo pesos for the refurnishing of their church. ${ }^{38}$ Here we have, then, a fine example of a peninsular royalist official who seems to have attracted the gratitude and support of the Indians against the material interests of an important representative of the local patriot-minded creole elite. Incidents such as these suggest that the tributary Indians used peninsular officials as a check against the pretensions of the local creole landowners. In the course of the following years, the tributary Indians on several occasions took up arms to defend the royalists in Santa Marta. Of course, in other areas of Spanish America, local conflicts developed differently. Sometimes, no doubt, peninsular rather than creole landowners were the principal contenders of Indian land. In places with a record of prolonged brutality against tributary Indians by peninsular priests or royal officials, Indians were probably more likely to side with the rebels. ${ }^{39}$ Indeed, local conflicts of this type may be the most

Agustín Gutiérrez y Moreno to his brother José Gregorio, Santa Marta 5 Aug. I 8 ro quoted in I. Gutiérrez Ponce, Vida de don Ignacio Gutiérrez. Vergara y episodios históricos de su tiempo (I806-I877) (London, I900), p. 74.

38 Martínez de Aparicio to the King, 25 Nov. 18 io and 36 th acta of the Junta de Santa Marta, 24 Nov. I 8 Io both in AGI, Santa Fe 746.

${ }^{39}$ For examples of tributary Indians fighting for the rebels, see for instance E. Van Young, 'Agrarian Rebellion and Defense of Community: Meaning and Collective Violence in the Late Colonial and Independence-Era Mexico,' Journal of Social History, vol. 27, no. 2 (1993) and M. T. Ducey, 'Village, Nation, and Constitution: Insurgent Politics in Papantla, Veracruz, I 8 I 10-182 I,' Hispanic American Historical Review, vol. 79, no. 3 (I 999). 
easily identifiable cause for Indian participation on either side during the wars.

However, in such a line of reasoning we are left with a perspective within which creoles fought for elevated ideological reasons, to establish a new society, to carry out a political revolution, while the Indians come out, in a more mundane and less interesting fashion, as fierce defenders of their own material and economic interests. Responding to this, Eric Van Young, suggested that while the Indian communities of Mexico during the independence era fought for such material concerns as communal lands and grazing rights, this was only ' ... one aspect of a broader, ongoing struggle of cultural resistance'. ${ }^{40}$ The Indians described by Van Young fought for an village utopia, implying that they saw their communities as somewhat outside the colonial state, and that the Indians' struggle, whether aligned for or against the republican insurgents, was just one episode in a long process of communitarian defence. In other words, it is possible that what the masingas, mamatocos, bondas, tagangas, gairas and cienagueros defended during the wars of independence, was primarily their local village and its customary rights. If this type of resistance may be labelled cultural without stretching the term too far, then Van Young's approach may work for the towns around Santa Marta as well.

However, from the Santa Marta case one may also argue that it was first and foremost a conflict between political ideologies. Indian support for the royalists in Santa Marta may be seen as a logical defence of a type of society that honoured the Indians' privileged corporate position, and that they foresaw that a liberal republic based on the principle of citizens equal before the law would threaten their communities, in both political and material terms. The problem with this view, of course, is that then one would expect all tributary Indians across Spanish America to have supported the royalists, which they did not. This paradox could be explained through how well the corporate privileges were upheld. In those regions, such as the interior of New Granada, where Indian communities had been invaded by non-Indian subjects and where many of the communal institutions had disintegrated decades before independence, the tributary Indians would have had little incentive to fight for a regime that did not defend their legal privileges. In Santa Marta, on the other hand, these privileges were honoured and in fact strengthened during the second half of the eighteenth century, and there was therefore a real point in defending them.

In Santa Marta the tributary Indians did not limit their participation in the wars to when their own lands or villages were at stake. One of their most remarkable involvements in the war occurred in March I 8 I 3, when mamatocos and bondas united under the leadership of the octogenarian cacique Antonio

40 Van Young: 'Agrarian Rebellion,' p. 262. 
Núñez to oust General Pierre Labatut who had conquered the city two months earlier for the republicans. This royalist reconquest and the ensuing political participation of the tributary Indians may be interpreted as an indication that the mamatocos, bondas, gairas, tagangas, masingas and cienagueros held political convictions which went beyond the material and cultural interests of their own villages. Although the Indians did not directly take up the government of the city, their military role gave them a moral capital which they actively used to gain influence. Not only did they imprison without trial 'hundreds' of creoles whom they suspected of secretly supporting Labatut and the rebels, moreover they refused to release the prisoners even when the new governor Pedro Ruiz de Porras arrived in May I 8 I 3. When the newly appointed captain-general of New Granada, Francisco de Montalvo, arrived in Santa Marta in June $18 \mathrm{I}_{3}$ he found that the '... pueblo believes ... rightly or wrongly that [the prisoners] are addicted to independence, and is irritated by the mere suggestion that some of them should be freed ...', apparently including in the term 'pueblo' the residents of the surrounding towns whose presence in the provincial capital from now on was manifest. ${ }^{41}$

During the ensuing years when the royalists controlled the city of Santa Marta, the influence of the Indians only increased. Clearly, the royalists depended on their continued support and paid heed to their interests and views. Montalvo, on another occasion, reported that Governor Ruiz de Porras distributed arms to the tributary Indians which they used to confiscate goods from the haciendas of wealthy creoles presumed to be supporters of the insurgency whom the Indians called Jacobins. ${ }^{42}$ An even more astonishing example of tributary Indians' political influence in these years occurred when they refused to accept the new governor appointed in I 8 I 4 . In a letter to the captain-general the Indian authorities of the tributary towns expressed their concern about the newly appointed governor, reiterated their support for interim Governor Ruiz de Porras, which in turn led both Montalvo and Ruiz de Porras to accede to their demands. Consequently, Ruiz de Porras remained as governor until the final republican victory in I $820 .{ }^{43}$

The tributary Indians around Santa Marta experienced some glorious years between I8I 3 and I820. They secured honorific titles for their leaders, enlarged their landed properties, directly interfered in the government of the city and enjoyed a political status commensurate with their loyalty to the crown. Perhaps the symbolic climax of this Indian-Spanish alliance occurred

41 Montalvo to Secretario de Estado, Santa Marta 22 Aug. I 8 I 3 in AGI, Santa Fe 746.

${ }^{42}$ Quoted in R. Earle, Spain and the Independence of Colombia, I810-1825 (Exeter, 2000), p. 46.

43 AGN, Solicitudes 3, folios 89-96. 
on 25 July I8 I 5 , the day of Spain's patron saint Santiago. General Pablo Morillo, commander of the Spanish expeditionary army sent to subdue to the rebels in northern Spanish America, honoured the cacique of Mamatoco Antonio Núñez for his loyalty to the royal cause by hanging a ribbon around his neck and handing him a diploma on the beaches of Santa Marta in front of the 5,000 Spanish soldiers under Morillo's command. ${ }^{\mathbf{4 4}}$

The Indians fought for the royalists until the bitter end. By November I 820 , the republicans controlled the coastal provinces, except the city of Cartagena which was besieged from October i 820 and the area around Santa Marta city. Bolívar had entered the viceregal capital in I 8 I 9 after the battle of Boyacá which effectively let him control the interior provinces, and in neighbouring Venezuela Pablo Morillo prepared the retreat of his troops. In Santa Marta, however, the tributary Indians and some of the peninsular officials did not give up easily. In November I 820 the royalists of Santa Marta prepared for a last major battle in Ciénaga against the combined forces of republican generals Carreño, Carmona, Brion and Padilla. In order to defend this strategic point, the royalists formed a force consisting of $\mathrm{I} 800$ soldiers, most of whom were tributary Indians from the town of Ciénaga itself and the other five pueblos. Characteristically, the commanders were non-Indians and leader of the entire operation was General Sánchez Lima while commoners Vicente Narciso Crespo and Thomas Pacheco of Santa Marta each commanded one division. The only Indian commander was Captain Jacinto Bustamente, the cacique of Ciénaga. Among the bloodiest battles of the wars of independence in this part of South America, 800 royalist soldiers (most of them Indians) and I 50 republicans fell during the battle of Ciénaga. Carreño, one of the republican generals, later commented that ' ... the enemy, mostly Indians, as brave as the best troops, entered the houses of the town, defended themselves with great obstinacy ... ${ }^{45}$ The bloody fall of Ciénaga stands in sharp contrast to the peaceful surrender of creole-led Santa Marta city. When the republicans had taken Ciénaga, the cabildo of Santa Marta immediately proposed an armistice in order to reach a capitulation, to which Carreño agreed. ${ }^{46}$ Governor Ruiz de Porras fled before the republican troops entered the city. ${ }^{47}$ With the peaceful capitulation

44 'Expediente sobre haver condecorado el Capital General Don Pablo Morillo con una medalla de distincion al Cacique de Indios Don Antonio Nuñez' and Morillo to the Secretario de Estado y Despacho Universal de Indias, 27 July i 8 i 5 both in AGI, Santa Fe I 20 I.

${ }^{45}$ Carreño to Bolívar, Ciénaga, i Nov. I 820 in M. E. Corrales (ed.), Documentos para la historia de Cartagena, vol. 2 (Bogotá, I 883), p. 427.

${ }^{46}$ Cabildo of Santa Marta to Carreño, Santa Marta io Nov. i 820 in Corrales, Documentos, p. 428.

47 Montilla to Bolívar, Santa Marta, I9 Nov. I 820 in Corrales, Documentos, pp. 429-3I. 
of Santa Marta, the republican forces at least formally controlled the entire province of Santa Marta.

Small royalist guerrilla groups still remained in the province of Santa Marta. Tributary Indians united with Spaniards and a few royalist creoles in some pueblos of the province to continue the armed struggle against the republicans. ${ }^{48}$ Led by cacique Jacinto Bustamente of Ciénaga and a handful of royalist Spaniards, the Indians invaded the city of Santa Marta and held it for three weeks in October $1822 .{ }^{49}$ In despair, republican leaders including Governor Rieux and Carmona fled to Taganga, only to be arrested by the tagangas and handed over to the royalists. ${ }^{\mathbf{5 0}}$ While they were in control of the city, the royalist rebels removed furniture and doors which were used as firewood for the bonfire they lit up in the streets. Mr Fairbanks, a British merchant who was living in Santa Marta at the time, complained that they had drunk all the liquor he had in store, and used the Bordeaux wine and the champagne for cooking. ${ }^{51}$ This was the last time that the tributary Indians in union with peninsular royalists posed a real threat to the republican security of the city of Santa Marta. In the course of 1823 , the last remaining royalist forces were rounded up.

\section{Republican redefinitions}

The establishment of the republic and the defeat of the last royalist forces brought fundamental and long-lasting changes to the pueblos around Santa Marta. At first the mamatocos, gairas, tagangas, cienagueros, masingas and bondas suffered drastic penalties, as renowned enemies of the republican cause. While some wealthy peninsulares and creoles who had supported the royalist cause were dispossessed of their properties or asked to leave the city, the most severe punishments were meted out to tributary Indians who had served as royalist troops. Some were sentenced to death or deported to prisons in Chagres and Panama, others to the newly established penal colony of San Sebastián de Rábago in the higher reaches of the Sierra Nevada. Many mamatocos, gairas, tagangas, masingas, bondas and cienagueros were forced to fight for the liberation of Peru and Bolivia after $1820 .{ }^{52}$ Of course, they were

48 J. Páez, Noticias históricas de la ciudad y provincia de Ocaña desde I8Io hasta la guerra de tres años (Cúcuta, I924), pp. 50-79.

49 J. M. Restrepo, Historia de la revolución de Colombia, vol. 5 (Medellín, 1969), pp. 10-17 and J. M. Groot, Historia eclesiástica y civil de Nueva Granada 2. ed. vol. 4 (Bogotá, I893), pp. 293-6.

50 J. C. Alarcón, Compendio de historia del Departamento del Magdalena (Bogotá, I963), pp. 107-1.

51 C. S. Cochrane, Journals of a Residence and Travels in Colombia during I823 and I824 (London, I 825), p. 59; Restrepo, Historia, pp. 10-17.

52 Vargas, Anotaciones, pp. I 33-9; P. Castro Trespalacios, Culturas aborígenes cesarenses $e$ independencia de Valledupar (Bogotá, 1979), p. I 35 ; Alarcón, Compendio, pp. 107-10. 
also forced to provide loans to the new republican regime in money or kind. ${ }^{53}$ These measures were meant to serve the republican cause both by providing it with useful resources and by punishing its most renowned enemies.

The punishments were also a sort of purification which the royalists underwent in order to be cleansed from their wrongful political convictions and which subsequently enabled them to become part of the new republican society as citizens. For the most ardent republican ideologues saw no impediment to the inclusion of Indians into the republic. ${ }^{54}$ On the contrary, during the first years after independence there existed great optimism among republicans about the future of the former Indians. In the somewhat longer run, the most notable change for the former Indians is the process in which they ceased to be identified as Indians and became simply lower-class rural Colombians. Our present knowledge of this integration of the former Indian communities into a new republican nation is limited; nevertheless it is possible to outline some tendencies that illustrate it.

The most obvious sign is the sudden disappearance of the term 'Indian' in early republican official discourse. After independence, the inhabitants of Gaira, Bonda, Mamatoco, Taganga, Masinga and Ciénaga were no longer referred to as Indians in censuses or parish records. Officially, the only Indians were those who in the colonial period had been defined as uncivilised Indians: the guajiros, the arbuacos, the chimilas and the motilones. This shows the new way in which republican society was conceptualised, where genealogical or historical descent should be irrelevant as a criterion of political rights, and where all in principle should be citizens irrespective of birth and social status. It is also worthwhile noting that only sporadically was the term 'Indian' used in other sources such as legal documents, newspaper articles or even in personal correspondence when writers referred to the inhabitants of these towns after independence..$^{55}$

The blurring of social boundaries can also be witnessed on a more mundane level. When former Indians married, they found partners from a much wider spectrum than previously. During the late colonial period, practically all brides and grooms who married in Gaira were born and resident there and classified as Indians in the census, and no one from Gaira married in the city

53 One example is Múnive to cabildo of Gaira 24 Nov. I 820 where he demands that the town deliver eight bulls by four o'clock the next morning. Biblioteca Luis Angel Arango, Manuscritos, Casa de Moneda, Db oo84, folios $4 \mathrm{ff}$.

54 The Congress of Cúcuta (I $82 \mathrm{I}$ ) declared that 'indios' henceforth should be called 'indígenas' and would be considered citizens electable to any political office.

55 One notable exception can be found in Francisco Cardona to Anselmo Pineda, 8 March I 842: in Ciénaga '... Hoy no hay más guarnición que 24 indios de tropa.,' BN, Manuscritos, Libro 437, folios 193-4. 
of Santa Marta between 1772 and $1788 .^{56}$ After I 820 , however, this situation changed rapidly, as illustrated by the distribution of surnames. In I 804 the 257 males in Gaira had only 25 different surnames. Comparing the surnames of the I 804 male count with the surnames of those who married in Gaira between 1793 and 1820 on one hand, and those who married between I 820 and 1850 on the other, we find that the difference is remarkable; while only I I brides and I I grooms (8.1 5 per cent) had 'new' surnames between I 793 and I 820 , between I 820 and I 85027 brides (28.I 3 per cent) and 25 grooms (26.04 per cent) had surnames found neither in I 804 census, nor in the late colonial marriage records. This suggest an immigration of non-Indians into the parish, more contact between the former Indian parish and the rest of the population in the area, and in a more general vein, a loosening of boundaries which during the colonial period had separated the tributary Indians from other non-elites.

Marriage records may be used to substantiate another fundamental change in the pueblos: a new, liberal and anti-authoritarian attitude towards marriage and sexuality and a denial of religious and political conservatism which before independence had characterised these towns. In all the former tributary towns there was a considerable drop in marriage quotients, in Gaira from 44.8 I per cent in 1793 to I 6.I 9 in I 843 , and while the annual average was five marriages between 1793 and I8I9, there were only 3.2 marriages a year between 1820 and 1850 despite a doubling of the population. ${ }^{57} \mathrm{~A}$ variety of causes may also explain the sudden drop in marriage quotients after independence, some of which are hard to assess due to the lack of general demographic statistics. There may have been proportionately more children in 1843 than in 1793 , and thus a relatively smaller 'marriageable' population. Alternatively, the average age at marriage may have increased, leaving a larger percentage of the population unmarried at any given point in time. ${ }^{58}$ The shortage of priests may have made it easier to evade marriage, as there were only 63 parish priests in the entire province in I 843 while there had been I $3 \mathrm{I}$ in 1793 for a much smaller population. ${ }^{59}$ However, the pueblos discussed here do not seem to have been less served by priests after independence than

Based on LG, LPMN and Libro de matrimonies de la catedral I $828-1832$ and the 1804 count of males in Gaira, AGN, Censos 6, folios $582-7$.

59 Marriage quotients and number of priests overall in the province can be deduced from the summaries of the $1778,1825,1835$ and 1843 censuses published in M. Urrutia and M. Arrubla (eds.), Compendio de estadísticas históricas de Colombia (Bogotá, I 970), tables I-7, pp. I 9 ff. The 1793 census is found in AGI, Indiferente general I 527 . For the shortage of priests, see also 'República de Colombia. Obispado de Santa Marta. Cuadros que manifiestan el estado personal del Clero secular y Regular de la diocesis ...', 3 I Aug. I 836 in AGN, Curas y obispos I 5 , folio 724 . 
before, and the considerable drop in marriage quotients was a general phenomenon which affected both parishes with priests and those without. In other words, the drop in the number of marriages cannot be explained exclusively by the lack of priest, and at least in part was due to a generalised indifference towards the most basic of catholic institutions. ${ }^{60}$ The former Indians were also indifferent to other sacraments. In 1829 the parish priest of Gaira reported to the bishop that in his parish only 25 individuals had fulfilled the annual precept of confession and communion, of whom 20 were women. The priest explained that these were less than one thirtieth of those obliged to confess. He claimed that not only did the inhabitants look with indifference at 'the Sacred Religion of Jesus Christ, and far from humbly performing this obligation ... they utter burlesque expressions ... ${ }^{61}$

The relaxation of religious sentiment represents a clear break with the late colonial period, when the tributary Indians were often defined precisely by their traditionalism, their profound Catholicism and the corollary dutiful payment of tribute to the king as the ultimate protector of the Catholic Church. ${ }^{62}$ The weakening of the tributary heritage and the rejection of a special status within the early republican regime also manifested itself when the inhabitants of the former tributary towns around Santa Marta refused to pay the so-called voluntary contribution Bolívar sought to introduce in I 827. Governor José Ignacio Díaz Granados explained in I83 I that the former Indians of the towns around Santa Marta refused to pay the contribution, that they abhorred such a system and that they preferred to pay normal taxes as ordinary citizens of Colombia. ${ }^{63}$

Perhaps the experiences of the independence wars led the former Indians to turn their back on both king and God? Certainly, the pueblos became focal points for several liberal rebellions and civil wars during the nineteenth century. Although these violent incidents have attracted some attention, most studies disconnect themselves from local social and cultural developments and focus exclusively on the role those incidents played as parts of nation-wide protests against national governments. Particularly during the War of Supremes, Ciénaga became a point of origin for the movement led by

60

For an excellent discussion of anticlericalism, although focused on elite attitudes, in early republican Colombia see D. Bushnell, El régimen de Santander en la Gran Colombia 3 rd ed. (Bogotá, i985), pp. 237-96.

61 De la Rosa Carrillo to bishop of Santa Marta, 24 Jun. i 829 in AHESM, tomo 35, folios I $20-I$.

62 Antonio Julián, as noted above, emphasised the religious fidelity of the tributary Indians in the eighteenth century. And it will be recalled that Martinez de Aparicio had to pay Ioo pesos for the refurbishment of the church in Mamatoco to appease the Indians there in I 8 I I during the conflict with Múnive y Mozo.

63 José Ignacio Díaz Granados to Secretario de Estado del despacho del Interior, 24 May I 83 I in AGN, Indios (Magdalena), folio 788 . 
the Venezuelan veteran of the Independence Wars, General Francisco Carmona against President José Ignacio de Márquez. Carmona’s troops were initially recruited in Ciénaga and he subsequently either recruited soldiers from Bonda and Mamatoco or obtained their political support. Commonly explained as a simple form of clientelismo, little is known about the possible political motivations for those who fought with Carmona or those, like the former cacique Jacinto Bustamente, who opposed him. Nevertheless, the reputation these towns gained as hotbeds of liberalism against the conservatism of Santa Marta is a phenomenon which merits further study. ${ }^{64}$ In any case, to dismiss these acts of political activism as merely the results of patronage and elite manipulations seem simplistic.

For it is clear that the pueblos were involved in the new republican politics, and not only as soldiers and cannon fodder. It will be recalled from the introduction that Guerra emphasised the role of modern forms of sociability: newspapers, elections, public schools, literary and political associations and books were essential for the construing of modern societies. Interestingly, the editors of the newspaper Gazeta de Santa Marta shared Guerra's view on the formation of a new public sphere. In one of their first issues in $182 \mathrm{I}$, they noted with satisfaction that among the subscribers there were two Indians from the former tributary towns. The Gazeta attached great importance to this readership: 'Among our subscribers', the Gazeta announced, 'we find the names of unexpected persons ... an Indian native of Mamatoco, the very dignified citizen Joaquín Vicente Muñoz, ... [and] the brave Captain Benito Malombo of Ciénaga, who has embraced the cause of Liberty with the enthusiasm of a man who is convinced of the great difference which exists between the domination of some intruders who only came to impoverish the country and bring back the riches to Spain from that of our own countrymen elected by ourselves ...' The newspaper celebrated the fact that it was attracting a wider public and emphasised the political meaning of this tendency. 'Let us picture', the editor proposed, 'the two illustrious Indians Joaquín Vicente and Captain Malombo in their respective towns seated at the doorstep of their houses surrounded by their relatives and friends, and perhaps even the entire town, reading the Gazeta. What a spectacle for a patriot! What a theme worthy of contemplation for a political philosopher! There we see, he would shout, the first effects of Freedom! ${ }^{65}$

64 On the War of Supremes, see F. Safford and M. Palacios, Colombia: Fragmented Land, Divided Society (Oxford, 2002), pp. 147-5 I; O. Fals Borda, El Presidente Nieto. Historia doble de la Costa -2 (Bogotá, 1986), pp. 57A-76A and 70B-76B; I. Correa Díaz Granados, Anotaciones para una historia de Ciénaga (Magdalena) (Medellín, I996), pp. 72-95; Sourdis, 'Ruptura del estado' pp. 204-1 2; Alarcón, Compendio, pp. 166-79.

65 Gazeta de Santa Marta, i9 May i 82 I, p. 8 in AGN, Archivo Restrepo, fondo I, vol. 9, fols. 208-9. 
Was this wishful thinking? Were newspapers in fact read aloud in the pueblos, and their contents discussed among the residents as the editors of the Gazeta imagined? 'Two subscribers to a local newspaper hardly amounts to a revolution, but this quote still illustrates the potential of the new forms of sociability and underlines the need for further research into the history of reading also in rural Latin America.

One of the most interesting aspects of the new republican politics is the extent to which the inhabitants participated in elections. Recently there has been a great interest in elections in nineteenth-century Latin America and these studies are beginning to give us new insight into the political possibilities open to non-elites. ${ }^{\mathbf{6}}$ Unfortunately, no studies on elections have so far been conducted for the early nineteenth-century Colombian Caribbean. Before 1853 , elections in Colombia were indirect and with a limited suffrage, conditions which may have caused historians wrongly to conclude that very few Colombians participated in the elections and disregard them as interesting objects of study for the popular politics of the early nineteenth century. ${ }^{67}$ Although the constitutions limited the suffrage to those who had a certain income, the income needed to qualify to vote was not very high. ${ }^{68}$ At least one indication that elections took place and attracted the attention of wide sectors in the former tributary towns also prior to 1853 can be deduced from a complaint published in Ciénaga in 1855 by local liberals. Furious that the man in charge of the polls at that date only accepted 600 of the 800 inscribed in the electoral roll for the elections of senators and congress representatives, they claimed that in '... past years in a local election there would be more than I 200 voters'. ${ }^{69}$ Apart from the rather high number of votes in a town which supposedly had only I,029 adult males in I 846, the letter also draws attention to the great interest in the elections by the inhabitants; an interest which one would presume would not exist if the result was of no practical consequence. ${ }^{\mathbf{7 0}}$

Obviously, independence did not produce societies devoid of social cleavages, and equal access to the public sphere. As Marx and Engels pointed out

66 Some are reviewed in H. Sabato, 'La ciudadanía el el siglo XIX: nuevas perspectives para el estudio del poder político en América Latina,' in H. J. König, T. Platt and C. Lewis (eds.), Estado-nación, comunidad indigena, industria. Tres debates al final del milenio (Ridderkerk, 2000), pp. 49-70.

67 Bushnell, for instance, holds that only io per cent of adult males had the right to vote in Colombian elections prior to I 853 in 'Las elecciones en Colombia: siglo XIX,' Credencial Historia 50 (Feb. 1994).

68 W. M. Gibson, The Constitutions of Colombia (Durham, NC, I 948).

69 'Los liberales de Ciénaga se quejan de los escrutinios' (Santa Marta, i 855 ) in BN, Fondo Pineda 998.

70 Number of males from census published in Estadistica jeneral de la Nueva Granada que conforme al decreto ejecutivo de I8 dic. de I846 publica la Secretaría de Relaciones Exteriores in BN, Fondo Pineda 876. 
in $1848, ' \ldots$ modern bourgeois society that has sprouted from the ruins of feudal society has not done away with class antagonisms ... the epoch of the bourgeoisie possesses, however, this distinctive feature: it has simplified the class antagonisms. Society as a whole is more and more splitting up into two great hostile camps ... Bourgeoisie and Proletariat'. ${ }^{71}$ We need not accept Marx' theory on the causes of this process to appreciate that he captured a tendency which characterised many contemporary societies, in Europe but also in Latin America. The legal and social divides between ancien regime corporate groups and estates broke down and gave way to a simpler dichotomy based on a new set of markers, where ancestral rights and genealogy was not of the most important. Indeed, the accounts of foreigners who visited Santa Marta and adjacent areas in this period reflect the simplification of social divisions: as they did not distinguish between coloureds, Blacks, slaves, Indians, and commoners more generally. ${ }^{72}$ The acute French radical Elisée Reclús, who visited Santa Marta and the surrounding areas in I 855 , commented on his visit to Bonda, the most remote of the former tributary towns: 'Today the descendants of the old Tayronas experience a state of transition. They have not yet entered the current of civilisation ..., but neither do they live in their old fierce and savage liberty. They do not even speak the language of their fathers, and after the wars of independence, which turned them into soldiers and citizens, they lost their local patriotism in order to adhere to the great Colombian nation. In this new patriotism is found the seed of their future regeneration ... ${ }^{73}$

More research is needed to comprehend more fully the developments of the tributary communities in Santa Marta. In addition to developing the themes outlined in this article, it would be most useful to explore others such as land ownership, legal disputes, public ceremonies, fiestas and schooling. Although incomplete, the material surveyed in this article indicates that significant and radical changes were taking place as a consequence of independence even in this rather remote corner of Spanish America. There is reason to believe, therefore, that Guerra's 'new society' did not only exist in the minds of a few articulate elites, but that people labelled Indian also conceptualised a new society with a fundamentally new role for themselves.

${ }^{71}$ K. Marx and F. Engels, The Communist Manifesto (repr. Middlesex, 1967), p. 80.

72 A. LeMoyne, Viaje y estancia en la Nueva Granada (Bogotá, 1985), p. 19; M. M. Lisboa, Relación de un viaje a Venezuela, Nueva Granada y Ecuador (Bogotá, 1984), pp. 169-70.

${ }^{73}$ E. Reclús, Viaje a la Sierra Nevada de Santa Marta (Barcelona, I 990), p. 94. 